Bond University

Research Repository

\title{
Andrea Dworkin on the Biblical Foundations of Violence Against Women
}

Kelso, Julie-Anne

Published in:

Rape Culture, Gender Violence, and Religion

DOI:

10.1007/978-3-319-70669-6_6

Licence:

Other

Link to output in Bond University research repository.

Recommended citation(APA):

Kelso, J-A. (2018). Andrea Dworkin on the Biblical Foundations of Violence Against Women. In C. Blyth, E. Colgan, \& K. B. Edwards (Eds.), Rape Culture, Gender Violence, and Religion: Biblical Perspectives (pp. 83101). Palgrave Macmillan. https://doi.org/10.1007/978-3-319-70669-6_6

\section{General rights}

Copyright and moral rights for the publications made accessible in the public portal are retained by the authors and/or other copyright owners and it is a condition of accessing publications that users recognise and abide by the legal requirements associated with these rights.

For more information, or if you believe that this document breaches copyright, please contact the Bond University research repository coordinator 


\section{Andrea Dworkin on the Biblical Foundations of Violence against Women}

Julie Kelso

The metaphysical ground rules for male and female were set in Genesis, in the beginning. The implications have been comprehended deeply and honed into laws and practices. The implications go far beyond the letter of the law, especially beyond the specific small laws that regulate the when and how of intercourse. The implications honor the basic law, men's ownership of women through intercourse. (Dworkin 1987, pp.193-4)

In neo-liberal democratic societies, the last decade or so has seen a resurgence in second-wave feminist demands for women's safety in public spaces, but also especially in the private realms. ${ }^{1}$ Domestic violence is now being described as an "epidemic" across the world. According to the 2013 World Health Organisation Report, approximately 30 percent of women in the world are affected by intimate partner violence. In Australia where I live, on average one woman a week is murdered by her intimate partner. ${ }^{2}$ While there has been a suggestion recently that this revived focus on male violence against women is part of a fourth-wave of feminism, ${ }^{3}$ it is important to note that this wave's demands are remarkably similar to that of the second wave of feminism known as "radical feminism." In particular, in mainstream media we have seen the return of the 1970s radical feminist term "rape culture." One of the most infamous and certainly most divisive radical feminist figures of the 1970s, 1980s, and 1990s who worked tirelessly, as both a writer and an activist, towards revealing the nature of rape culture was the late Andrea Dworkin. In this chapter, my interest is with her argument that intercourse itself must be analysed robustly in its context of male- 
dominated and male-supremacist societies, indeed as one of its principal institutions. While Dworkin never actually claimed that all intercourse is rape (despite the habitual and continued insistence of that thesis in the mainstream media and in cyberspace whenever her name is mentioned), she does insist that women's lives could never be valued as properly human — in the existentialist sense of being essential rather than inessential lives - without an unflinchingly honest appraisal of intercourse in male supremacist societies. In other words, it is not the case that, for Dworkin, intercourse has always been and will always be demeaning for women, or that it is ontologically the same as rape. Rather, in societies that hold the male of the species as supreme and the female as delightfully incidental—a footnote to man's story or a moon orbiting around planet man — when asking why rape culture is able to persist, we must consider the role of intercourse itself.

When we think of the Bible and the issue of violence against women, we tend to go straight to those stories and legal texts that are well-known to us from decades of feminist work in the discipline. We are familiar with Genesis 34, Num. 31:7-18, 2 Samuel 13, Jdg. 21:10-24, the laws found in Deuteronomy $(21: 10 ; 22: 23-9)$, and the gendered language of violence in the prophets, just to name a few. In this essay, however, I want to explore Dworkin's discussions concerning the sodomy laws in Leviticus and the story of Adam and Eve in Gen. 2:4b-4:1 with respect to what she perceives to be their foundational role in the institutionalization of intercourse. Dworkin is interested in the religious and legal discourses that help to create the political meaning of intercourse and legitimize what she considers often to be the actual and devastating violence of the act for the woman in male supremacist societies: the erosion of the self and the compliant acceptance of lower status. I shall first explore her arguments concerning intercourse before moving to a discussion of her readings of 
the biblical texts. In what follows, I carefully seek to understand Dworkin's arguments in the context of the book (Intercourse) as a whole. Dworkin has been (naively) either demonized or hagiographized in the media and in the Academy, and both sides pick and choose passages from her work without attending to their immediate ideational context and thus without giving her the critical attention I believe her ideas deserve. ${ }^{4}$

\section{The Institution of Intercourse}

In her notorious book Intercourse (1987), Andrea Dworkin claims that women's second-class status is possibly attributable to the socially-constructed definition of our bodies as lacking in physical integrity during intercourse. In male supremacist societies like ours, "Woman" is constructed as that which is entered, penetrated, occupied, and denied privacy, and naturally so (Dworkin 1987, pp.144-6). As a strictly materialist analysis of intercourse, Dworkin's focus is on intercourse as an institutional practice distinct from intercourse as an unmediated individual experience (as if possible). As Jenefsky with Russo (1998) helpfully point out, this is akin to Adrienne Rich's now classic analysis of motherhood as an institution rather than any individual experience of motherhood (Rich 1976; Jenefsky with Russo 1998, p.99). As such, Dworkin's focus is on those discourses (literary, philosophical, religious, legal) that have effectively constructed the political meaning of intercourse in male-dominated societies. Her analysis concerns the broader and complicated relations of power within which the act takes place and which have historically made the subjugation of women through the act somewhat mandatory for their existence. For so long now and, Dworkin maintains, across all cultures, woman "is defined by how she is made, that hole, which is synonymous with entry" (1987, p.145). Dworkin points out that no other oppressed people are cast as "being made for intercourse: for penetration, entry, 
occupation" (ibid.). We cannot analogize this situation with colonial occupation, or racism, or the oppression and abuse of children, or the Gulag, for example, because, according to Dworkin:

There is nothing that happens to any other civilly inferior people that is the same in its meaning and in its effect even when those people are forced into sexual availability, heterosexual or homosexual; while subject people, for instance, may be forced to have intercourse with those who dominate them, the God who does not exist ${ }^{5}$ did not make human existence, broadly speaking, dependent on their compliance. (1987, pp.145-6)

It is this socially and religiously constructed determination of intercourse as "a means or the means of physiologically making a woman inferior" that underwrites all violence against women, indeed what naturalises it, according to Dworkin. And foundational to all of this, at least in the Judeo-Christian traditions, is "the metaphysical laws of dominance articulated in Genesis" (Dworkin 1987, p.195). For Dworkin, feminist thought in particular has more often than not been marked by a refusal to confront the political meaning of intercourse. This refusal marks not only conservative thinking, but liberalism and radicalism as well. She states: Intercourse is fun, not oppression. Intercourse is pleasure, not an expression or confirmation of a state of being that is either ontological or social. Intercourse is because the God who does not exist made it; he did it right, not wrong; and he does not hate women even if women hate him. Liberals refuse categorically to inquire into even a possibility that there is a relationship between intercourse per se and the low status of women. Conservatives use what appears to be God's work to justify a social and 
moral hierarchy in which women are lesser than men. Radicalism on the meaning of intercourse-its political meaning to women, its impact on our very being itself-is tragedy or suicide ... What intercourse is for women and what it does to women's identity, privacy, self-respect, selfdetermination, and integrity are forbidden questions; and yet how can a radical or any woman who wants freedom not ask precisely these questions? The quality of the sensation or the need for a man or the desire for love: these are not answers to questions of freedom; they are diversions into complicity and ignorance. (1987, p.147)

It is necessary to point out that Dworkin's thinking is heavily influenced by the existentialism of Simone de Beauvoir and Jean-Paul Sartre. She is particularly committed to the Sartrean and Beauvoirean ideal of freedom as autonomous living, where subjects are free to pursue their transcendence, forging projects of their own, but only on the condition of the freedom of others. Like Beauvoir (2011) before her, Dworkin maintains that this pursuit is more difficult for women, if even possible at all, because of their prescribed function as inessential "other" for men.

Dworkin thus rejects the 1960s and 1970s radical libertine mandate that sex is freedom, considering it yet another means whereby men get women to accept their lower status. With libertinism, thinks Dworkin, women do not experience their own sexual liberation, despite what they might think is the case; instead they are merely agreeing to give men what they want and in greater quantities. In Right-Wing Women (1983), Dworkin points out that in the late 1960s, prior to the rise of radicalized feminism in the US, the men of the counter-cultural New Left "agitated for and fought for and argued for and even organized for and even provided political and economic resources for abortion rights for women," because if abortion were not available to 
women on demand, then "fucking would not be available to men on demand" (p.95). With the rise of feminist consciousness came the demise of the men of the New Left's concern for women's abortion rights, as women began to see how they had been used as sexual objects: "The leftist men turned from political activism: without the easy lay, they were not prepared to engage in radical politics" (pp.97-8). ${ }^{6}$

Writing about Flaubert's Emma Bovary, Dworkin declares that with Emma the modern era begins, an era she describes as "the petite bourgeoisie seeking freedom" (1987, p.125). Emma's supposed liberation does not come about through increased education or economic reform, but through sex. Dworkin states with respect to Flaubert's novel: "Female freedom is defined strictly in terms of committing forbidden sexual acts. Female heroism is in getting fucked and wanting it" (ibid.). For Dworkin, the so-called sexual liberation movement of the 1960s and 1970s crystallises this delusion — that sex is freedom—of the modern era (p.169).

In her analyses of cultural products from pornography to high literature, Dworkin concludes that sexual intercourse currently cannot take place without the objectification of the woman. She wonders what intercourse could be like without objectification, whether it is even possible in societies drenched in the ideology of male power and dominance (Dworkin 1987, p.166). Clearly, Dworkin's analysis of an act that for many heterosexual women is not (always, or perhaps even often) unpleasant or overtly subjugating is confronting to say the least. And, I presume, many heterosexual men resent being told they are violators of women. It is well-known that Dworkin was and largely still is dismissed as "anti-sex" or "sex-negative" by her theoretical adversaries, male and female. This typecast dismissal harkens back to reactions to Dworkin's earlier book Pornography: Men Possessing Women (1989; first published in 1981), and her allegiance with the feminist lawyer Catherine MacKinnon, 
but then set in stone after the publication of Intercourse. Dworkin has indeed come to be understood as a thinker who rejects entirely what is known as heterosex in the West: intercourse. However, for Dworkin, the term "sex-negative" is "the current secular reductio ad absurdum used to dismiss or discredit ideas, particularly political critiques, that might lead to detumescence" (1987, p.57).

Intercourse, Dworkin argues, is understood as a sacred act by both the moral Right and the progressive Left, and as such cannot in itself be criticized. "Fucking" is a good thing, and this good thing is powerfully related to the idea of citizenship in "Amerika":

In Amerika, there is nearly this universal conviction — or so it appearsthat sex (fucking) is good and that liking it is right: morally right; a sign of human health; nearly a standard for citizenship. Even those who believe in original sin and have a theology of hellfire and damnation express this Amerikan creed, an optimism that glows in the dark: sex is good, healthy, wholesome, pleasant, fun; we like it, we enjoy it, we want it, we are cheerful about it; it is as simple as we are, the citizens of this strange country with no memory and no mind. (1987, p.55)

To analyse the function of intercourse almost equates to treason. To question the function of intercourse, to analyse and scrutinize the act in search of its concealed political, cultural, economic, and social service to men, is to render oneself silent in the process. Or rather, it is women who must subscribe to this simplistic promotion of intercourse (Dworkin 1987, p.56). The fact that Dworkin is today rarely engaged with in a substantial manner, ${ }^{7}$ or that her ideas are rarely taught except as of interest to those keen on the history of feminism, is perhaps testimony to the fact that Dworkin was right on one count at least: if you, a woman, criticize intercourse you will be silenced. 
In a sense, this is the main point of Intercourse: men are afforded the ability to describe intercourse in all its ambiguities, the good and the bad, while women must simply like it. ${ }^{8}$ We should also remember that Leo Bersani's (1987) famous sentence "There is a big secret about sex: most people don't like it" also appeared in the same year as Intercourse. To my knowledge, Bersani was not dismissed as a "sex-negative" thinker. ${ }^{9}$

As a consequence, this general prohibition against women criticising intercourse has led to gross distortions of Dworkin's analysis. Dworkin was and still is regularly charged with claiming in Intercourse that all intercourse is rape. Even those feminist sisters who have insisted on challenging the reduction of sex to intercourse find Dworkin too much to bear. This is because for such feminists - those who reject essentialistic or biologically determined understandings of male-female sexuality, as does Dworkin - Dworkin seems to dismiss all forms of heterosexual intercourse under patriarchy because of the physical difference between women and men. Consider the following oft-quoted paragraph:

This is nihilism; or this is truth. He has to push in past boundaries. There is the outline of a body, distinct, separate, its integrity an illusion, a tragic deception, because unseen there is a slit between the legs, and he has to push into it. There is never a real privacy of the body that can coexist with intercourse: with being entered. The vagina itself is muscled and the muscles have to be pushed apart. The thrusting is persistent invasion. She is opened up, split down the centre. She is occupied - physically, internally, in her privacy. (Dworkin 1987, p.143)

When we consider this passage out of context, ${ }^{10}$ it seems that Dworkin is quite clearly arguing that all intercourse is, if not rape, then an invasion, a violence perpetrated 
against the woman. Not only is this invasion physically violent, with muscles being pushed apart, but it is psychologically violent because a woman's sense of privacy (admittedly a modern conception of the individual) is negated through the act. Passages such as this one have led certain scholars to view Dworkin as a radically separatist feminist who insists that women refrain from intercourse with men because it has been, is, and will always be an undermining, indeed destruction, of a woman's ability to exist as a viable, self-determining subject in the world, a human being with integrity. The problem for such scholars is one of biological determinism: because of our physical differences, men will always control women through the act of intercourse; women will always be victims because of their objectification. ${ }^{11}$ But is this what Dworkin is actually saying?

First of all, Dworkin has always insisted that she never argued that all intercourse is rape. ${ }^{12}$ While not rape (and perhaps here is where the confusion begins), Dworkin does think that intercourse is a violent act. For example, in an interview with Michael Sheldon she states: "Penetrative intercourse is, by its nature, violent. But I'm not saying that sex must be rape. What I think is that sex must not put women in a subordinate position. It must be reciprocal and not an act of aggression from a man looking only to satisfy himself. That's my point" (2000). Does this mean that, despite any agency or intention on the part of the man, no matter his goodness, his kindheartedness or his desire for intimacy, by its very nature by having intercourse with a woman he is committing violence? It is interesting that Dworkin's comments about the possibilities of intercourse being "communion, a sharing, mutual possession of an enormous mystery; it has the intensity and magnificence of violent feeling transformed into tenderness" (1987, p.71) are rarely if ever quoted. Such possibilities are entertained all throughout Dworkin's oeuvre, especially the idea that it is a remarkably 
human accomplishment to transform what she believes (along with Freud and Bataille) to be the violent nature of eros into intimacy and tenderness. Yet, such aspects of her thinking never seemed to catch on, in the media or in the Academy. In other words, Dworkin believes it entirely possibly for human sexuality to be conceived as having "the intensity and magnificence of violent feeling transformed into tenderness" (ibid.); it is just that we do not live in a world with such a sexual script as the dominant one.

In the book itself Dworkin's concern is with the historically dominant depiction of intercourse as the occupation and possession of women by men, an act that sustains the sexual hierarchicalization of strictly differentiated genders necessary to male supremacist societies. Her concern is to de-naturalise all aspects of the act to reveal the ideology of male dominance at work, paying close attention to the possessive and militaristic language that overwhelmingly is employed to describe intercourse (Dworkin 1987, p.73). Thus, while intercourse is not ontologically the same as rape, because Dworkin refuses to consider intercourse as isolated from broader discursive influence, she asks us to consider the very intrinsic service of intercourse in male dominant societies, how these dominant scripts both create and maintain male power over women. And it is important to realise that Dworkin is making this argument through her critical analyses of predominantly male-authored literature. None of Dworkin's statements about intercourse are based solely on her own experience or anecdotal evidence: the book is largely about men and their conceptions and depictions of intercourse.

In the first section of the book, "Intercourse in a Man-made World," Dworkin provides five chapters that are careful and incisive analyses of important works of literature by men whom she has described as "phenomenal writers on issues of power and freedom" (1992)—notably Leo Tolstoy, Kobe Abe, Tennessee Williams, James 
Baldwin, and Isaac Bashevis Singer (I will focus only on her reading of Tolstoy, here). These chapters starkly reveal for Dworkin the truth of what men in male supremacist societies think of intercourse with women and how they are depicted as treating women before, during, and after the act.

Interestingly, Dworkin shows how intercourse, for these men at least, is not simple, enjoyable, and unproblematic, as is the banal yet dominant cliché about sexuality, especially the young, straight man's sexuality. For example, Leo Tolstoy's main character in his Kreutzer Sonata is driven by desire to have sex with his wife, only to be repulsed by her afterwards. In between their sexual encounters he is either cruel to her or he ignores her, until his desire gets the better of him and he wants to have sex with her again. ${ }^{13}$ As Dworkin points out, however, the repulsion felt for the wife is not caused by his disgust at her body or some puritan loathing of carnality itself. He loathes her because in intercourse her necessary inferiority to him becomes apparent. The great social critic of inequality (Tolstoy) believes intercourse must be eradicated if men and women are to be equal because intercourse makes exploiters of men and slaves of women:

[T]he enslavement of woman lies simply in the fact that people desire, and think it good, to avail themselves of her as a tool of enjoyment. Well, and they liberate woman, give her all sorts of rights equal to man, but continue to regard her as an instrument of enjoyment, and so educate her in childhood and afterwards by public opinion. And there she is, still the same and depraved slave, and the man still a depraved slave-owner. They emancipate women in universities and in law courts, but continue to regard her as an object of enjoyment. Teach her, as she is taught among 
us, to regard herself as such, and she will always remain an inferior being. (Tolstoy 1967, p.385)

Tolstoy's protagonist also loathes his wife (and ultimately kills her) because her sensuality renders him powerless to her charms, according to him. Because women are made to be inferior through their sexual objectification they enact their revenge, says Tolstoy, by enslaving men through sex. As Dworkin points out, the logic here is somewhat perverse: men are favoured by laws, rights, and privileges and yet they perceive themselves to be dominated by women in their revenge against men for their lower status. Yet, women can only achieve some perceived level of power by assuming their inferior status in intercourse, because otherwise men would not desire them (Dworkin 1987, p.19). It is crucial to note that it is Tolstoy who is arguing that intercourse reduces women to slavery. While Dworkin insists that intercourse must be rigorously analysed for its complicity in the maintenance of men's domination of women, it is Tolstoy who is in fact suggesting its elimination from human behaviour. To my knowledge, Tolstoy was never silenced because of this idea, nor deemed "sex negative." Again, it seems that it is only women who must not criticize the act.

\section{Law, Nature, and the (Biblical) Metaphysics of Male Supremacy}

Dworkin's discussion in Intercourse of Leviticus and Gen. 2:4b-4:1 occurs in Chapter Eight, "Law." This is the first chapter of the third and final section of the book, titled "Power, Status, Hate." This final section investigates the means by which intercourse has been and still is regulated through civil and religious institutions. Contrary to the idea that intercourse is simply a matter of choice and an act that takes place in privacy, Dworkin argues that the fact that religious and civil laws have always sought to control the determination of both legitimate and illegitimate sex is proof that intercourse is a 
social construct central to the institution of male supremacy (1987, pp.173-4). Historically, and until very recently (see below), the only privacy afforded the act concerns a man's right to use his wife for anything and in any way he wants.

There are three ways that legal restrictions on sexual activity maintain the strict gender demarcation requisite if domination of one over the other can occur. First there are those laws that insist that a man only have sex with someone not like him, that is, someone with a vagina and a womb. Dworkin quotes Norman Mailer, whom she describes as combining the best of both Proust and Leviticus when he writes:

Yes, it is the irony of prison life that it is a world where everything is homosexual and yet nowhere is the condition of being a female male more despised. It is because one is used, one is a woman without the power to be female, one is fucked without a womb. (Mailer, quoted in Dworkin 1987, 181)

Women are useful because of their capacity to reproduce for men. Indeed, argues Dworkin, in both Proust and Mailer the "real man" as opposed to the "female man" is affirmed by women's ability to reproduce, "with the whole meaning of the fuckgender-being resolved by its outcome in producing children. Sensual pleasure is not what distinguishes homosexual sodomy from heterosexual fucking: the woman bearing the child does_-in religion, in Mailer" (Dworkin 1987, p.182). Sodomy laws are thus obviously related to those laws that regulate what exactly a man can do to a woman, when and why (p.184).

The second form of regulation concerns laws that prevent men from being treated like women, that is, penetrated. These are the biblical sodomy laws themselves. Dworkin argues that all laws concerning sexuality, especially the sodomy laws deriving from Leviticus ("Thou shalt not lie with mankind, as with womankind; it is an 
abomination," 18:22; "And if a man lie with mankind, as with womankind, both of them have committed an abomination: they shall surely be put to death; their blood shall be upon them," 20:13) ${ }^{14}$ along with the cross-dressing law in Deut. 22:5 ("A woman shall not wear that which pertaineth unto a man, neither shall a man put on a woman's garment; for whosoever doeth these things is an abomination unto the Lord thy God"), are there to maintain a strict demarcation of gender, so that the heteronormative hierarchy of man over woman can be maintained. When gender is blurred, particularly in sexual acts, male supremacy as a system of power becomes less potent.

Dworkin is particularly interested in sodomy laws and how their true purpose, according to her, is to maintain man's civil and sexual superiority over women through the controlling of the lust of men. The logic is that if men as a class are dominant, each male feels it his right to dominate another, anyone he might choose. However, if he starts to dominate another man instead of a woman, then these men have to endure what women are there for in the service of male supremacy, and "naturally" so. Dworkin begins her discussion with Augustine's association of lust with dominance. Before the fall, thinks Augustine, man and woman had sex without lust: "a man and his wife could play their active and passive roles in the drama of conception without the lecherous promptings of lust, with perfect serenity of soul and with no sense of disintegration between body and soul" (Augustine 1958, p.318). In Eden, before the fall, we see the dichotomized gender positions as active and passive, even without lust. Sodomy, according to Augustine, is a sin against nature, male nature at least, as created by his God, and thus a crime against his God. As Dworkin points out, despite the centuries between them, both Mailer and Augustine are remarkably similar in their descriptions of the lust of dominance as: 
an ecstasy, a frenzy, cruelty, all-encompassing, dominance in the fuck as a supreme and superb pleasure. Men are not supposed to have to endure being the victims of this lust; perhaps there is an implicit recognition that the subordination itself, the carnal experience of it, would change them, their so-called nature - create in them the incompleteness, the low selfesteem, so commonplace in women under male dominance. $(1987$, p.183)

Sodomy laws are there to protect men as a class from the degradation of being made woman-like. In the Judeo-Christian traditions, sodomy is understood as an abomination, a violation of male nature such that it presents "a nightmare vision of one kind of sexual equality: men used by men as women are in sex to satisfy the lust for dominance expressed in the fuck" (Dworkin 1987, p.183).

Relatedly, the third category concerns those laws that maintain male control over their women, adultery laws and rape laws especially. The issue for Dworkin, with respect to these laws, is one of restraint. While it is obvious that the controlling of women's and men's sexual activities is an integral part of social organization, what Dworkin argues is that the morality often behind these laws is also, as she puts it, "brilliantly pragmatic. Male dominance does best, after all, when men do not, generally speaking, fuck themselves to death by fucking whatever moves. Restraint is a key to power" (Dworkin 1987, p.186). Men must not fuck other men's women because this depletes the power of men as a class by causing conflict between them (p.190).

For Dworkin, the legitimation of rape in marriage, which she worries now extends beyond marriage to include the rights unmarried men have over unmarried women, derives in our culture at least not just from the biblical laws concerning legitimate and illegitimate sexual practices but from the story of the first man and woman in Gen. 2:4b-4:1, where she claims that "the metaphysical ground rules for 
male and female were set" $(1987,193)$. While in the first version, as we know, there is a possible reading of equality between the sexes ("And God created man in His own image, in the image of God created He him; male and female created He them," Gen. $1: 27)$, the second creation myth clearly makes woman subservient to man (Genesis 2); she is "made for him from him; bone of his bones, flesh of his flesh; and God affirms they are 'one flesh"” (Dworkin 1987, p.191). It is because of this version that, as Dworkin puts it, "jurists for centuries after recognized a man and his wife as one flesh: the man's" (ibid.). And the reason for this is that in the second story we get a strict separation of humanity into two genders, whereas the first story hints at their sameness.

In her reading of the story, when Eve eats from the forbidden fruit, her "natural" inferiority is manifest, allowing herself to be seduced by a snake. Having disobeyed God and seduced Adam into eating the forbidden fruit, it seems that her difference from him becomes most apparent: "All of the bone-of-my-bones business disappears, in a sense for ever. She and he are 'one flesh' in that he has sovereignty over her body; but they are different from then on, her bones not reminding one of his at all, her flesh so different from his that it might as well have been made out of some different material altogether" (Dworkin 1987, p.192).

Here, Dworkin's thinking is reminiscent of Simone de Beauvoir's existentialist reading of the biblical first man and woman (2011, pp.164-5). For Beauvoir, the second creation story in Genesis, like all creation myths in her view, expresses man's self-servingly necessary conviction that woman is his inessential other. Upon her (unorthodox) Hegelian reading, woman is thus:

the perfect intermediary between nature that is foreign to man and the peer who is too identical to him. She pits neither the silence of nature nor the hard demand of a reciprocal recognition against him; by a unique 
privilege she is a consciousness and yet it seems possible to possess her in the flesh. Thanks to her, there is a way to escape the inexorable dialectic of the master and the slave that springs from the reciprocity of freedoms. (Beauvoir 2011, p.164)

The Genesis myth, for both Beauvoir and Dworkin, reveals how woman is conceived by man as a being who, as "a naturally submissive consciousness" (Beauvoir 2011, p.165), is able to become the property of man, as “one flesh: the man's" (Dworkin 1987, p.191). Both Beauvoir and Dworkin pursue the historical outcomes of this "othering" of woman, exploring the effects of this biblically gendered metaphysics of dominance on women who are "privileged prey" (Beauvoir 2011, 165). For Dworkin, this becomes clear in the Genesis myth if we continue to read beyond the fall. Eve is famously cursed with pain in childbirth, desire for her husband, and she is made subservient to him (Gen. 3:16). Immediately upon their expulsion, in Gen. 4:1, Adam has intercourse with Eve and she bears Cain: “And Adam knew Eve, his woman, and she conceived and bore Cain and she said 'I have gotten/acquired a man from/with Yahweh"” (qanîtî 'îsh et yhwh). ${ }^{15}$ The issue of Eve's consent is obviously unimportant. Furthermore, Adam and Eve do not walk out of paradise and straight into a story concerning Adam's punishment of life-long toil, nor do they emerge from the garden and get attacked by snakes; we go straight to intercourse and the issue of man's dominion over woman. So, summarises Dworkin: "Eve's curse is in the pain of childbirth and in feeling desire for her husband; they are her punishments. The rule of the husband over the wife is in sexual intercourse; his sovereignty over her is in the fuck" (1987, p.192).

We might claim that Dworkin's (and Beauvoir's) sentiments concerning Gen. 2:4b-4:1 and the Levitical laws are no longer relevant, given the current (prima facie) 
recognition of women as "humans" with attendant rights. In particular, the idea that a man owns his wife seems rather outdated. However, it is quite astonishing to remember that for most western countries it was only in the last decades of the twentieth century that laws admitting the possibility of raping one's wife came to be enacted. ${ }^{16}$ In other words, until recently the law in all liberal democracies insisted that woman belonged to her husband and part of his ownership concerned his freedom to fuck her whenever he wanted, despite her desire. And for Dworkin, “men's ownership of women through the fuck" derives in our biblically-based cultures from the Genesis myth. We might think that we have moved well beyond such a patriarchal proprietary model. However, research into the recent alarming rises in the number of women in western societies who are raped, abused, and murdered by their intimate partners, married or not, suggests otherwise. So too does the well-documented form of male on-line aggression towards women, in order to silence them, which is overwhelmingly expressed through language of extreme sexual violence. ${ }^{17}$ However, while there currently is much outrage from men and women over this rise in violence against women, Dworkin cautions us that social outrage might not be as trustworthy or as progressive as we might think. She says:

Social outrage is power protecting itself; it is not morality. There is always a tension between the law that protects male power-basic fundamentalism, religious or secular — and men's wanting to break that law: exercise the privileges of power for the sake of pleasure ... How much license can men take without destroying the effectiveness of the laws that formally restrain them in order to protect their power as men? ... The regulation of men by men in sex for the sake of upholding the power 
of men as a class is the least recognized, least scrutinized aspect of male dominance and law as an institution of social control. (1987, pp.188-90)

Thus, we might say, just as in the ancient world of the Bible the so-called "rape laws" did not recognise the woman as the victim (the victim generally understood to be the father or the husband), despite appearance to the contrary, rape laws today are still protecting men from a potentially depleted access to resources: women.

\section{Conclusion}

For Dworkin, violence against women, especially domestic abuse and rape, cannot be understood or even attended to without a rigorous and uncompromising analysis of the meaning of intercourse itself as constructed within societies that hold the man as the supreme being; the only one with any real right to self-determination and indeed humanity. Now, of course, not all men have the same levels of power in society, and Dworkin acknowledges this as such. However, the physical differences between men and women are always conceived and experienced within a male-dominant context (Dworkin 1987, p.148).

The question of whether intercourse could express sexual equality is a difficult one because, Dworkin says, "How to separate the act of intercourse from the social reality of male power is not clear, especially because it is male power that constructs both the meaning and the current practice of intercourse as such" (1987, p.150). Intercourse is not and has never been a private act. Indeed, Dworkin argues that the classic second-wave radical feminist slogan "the personal is political" is ironically in principle the logic of patriarchal law itself, where the social rights given to men in male supremacist societies are translated to the private sphere, where men (still) hold rights of ownership over women. She states: "The principle that 'the personal is 
political' belongs to patriarchal law itself, originating there in a virtual synthesis of intimacy and state policy, the private and the public, the penis and the rule of men" (p.187). All of the laws around legitimate sexual practices, including those that formally restrain men are, according to Dworkin, instituted to protect male supremacy itself, both within the home and beyond. And crucial to the maintenance of this ideology is the subjugation of women as "owned through the fuck" (p.188).

Certain reforms are of course necessary to the task of women's liberationeconomic equity; the election of women to political office; progressive role models for girls; emphasis on the physical strength of women's bodies; effective rape laws and strategies to diminish the incidences of violence against women. Moreover, Dworkin recognizes that reforms around women's sexuality have also been necessary-foreplay that defers to female sensualities; less verbal assault of women; the eradication of the romanticization of rape, to name a few (1987, pp.149-51). However, while these reforms might be necessary to the task, they are not in themselves sufficient because for Dworkin they do not address the main question: "Is intercourse itself then a basis of or a key to women's continuing social and sexual inequality?" (p.151).

In other words, Dworkin sees no point in trying to rethink intercourse without recognizing its formative function as an institution of male domination and supremacy. She recognizes that women and men do experience pleasure in intercourse, but thinks it is most likely because we have internalized those binary gendered erotics of male dominance and female submission, even if we simply swap roles. We could imagine the female body as hospitable, as Irigaray does in her oeuvre, for example, rather than as occupied territory. ${ }^{18}$ Perhaps her body can be conceived of as welcoming the male, with enough preparation, such that no violence is intended or experienced. The question Dworkin insists on asking, though, is how such a rethinking could dismantle 
the broader structures of male dominant society, because until such a dismantling occurs intercourse will remain in its service as its most brilliantly effective tool because of the concealment of its mechanisms in pleasure. What we see from Gen. $2: 4 b-4: 1$ and the Levitical laws concerning sexuality is that this institutionalization of intercourse is entrenched at the base of our male-supremacist culture, a base we sadly deem sacred.

\section{Reference List}

Augustine. 1958. City of God. Translated by G.G. Walsh, Demetrius B. Zema, Grace Monahan, and Daniel Honan. New York: Doubleday.

Brecher, Bob. 2013. "Pornography, Patriarchy and Liberalism: Re-Reading Andrea Dworkin." The New Left Project. http://www.newleftproject.org/index.php/site/article_comments/pornography p atriarchy and liberalism re reading andrea dworkin. Accessed 28 April 2017.

Dworkin, Andrea. 1983. Right-Wing Women. New York: Perigree.

Dworkin, Andrea. 1987. Intercourse. London: Arrow.

Dworkin, Andrea. [1981] 1989. Pornography: Men Possessing Women. New York: E.P. Dutton.

Dworkin, Andrea. 1992. Modern Times interview with Larry Josephson. Radio Programme, American Public Radio. Transcript. http://www.andreadworkin.com/audio/moderntimes.html. Accessed 28 April 2017.

Dworkin, Andrea. 1995. "Fighting Talk.” New Statesman and Society. Interview with Michael Moorcock. 21 April. 
http://www.nostatusquo.com/ACLU/dworkin/MoorcockInterview.html. Accessed 28 April 2017.

Dworkin, Andrea. 2006. "Preface." In Intercourse. Twentieth Anniversary Edition. New York: Basic Books.

Echols, Alice. 2002. Shaky Ground: The Sixties and its Aftershocks. New York: Columbia University Press.

Irigaray, Luce. 2004. "The Wedding between the Body and Language.” In Luce Irigaray: Key Writings. Ed L. Irigaray, 13-22. London and New York: Continuum.

Jenefsky, Cindy, with Ann Russo. 1998. Without Apology: Andrea Dworkin's Art and Politics. Boulder, Colorado: Westview Press.

Kelso, Julie 2016. "The Institution of Intercourse: Andrea Dworkin on the Biblical Foundations of Violence against Women.” The Bible and Critical Theory 12 (2): 24-40.

Lucas, Peter. 2011. Ethics and Self-Knowledge: Respect for Self-Interpreting Agents. Library of Ethics and Applied Philosophy 26. Dordrecht: Springer.

McNally, Gillian. 2015. “'All Feminists Should Be Gang Raped': Inside the Disturbing World of Online Misogyny. Daily Telegraph, 30 July. http://www.dailytelegraph.com.au/news/nsw/why-do-men-threaten-womenwith-rape-to-shut-them-up-on-the-web/newsstory/0abd8403e59747a51717f54b81a21b46. Accessed 5 May 2017.

Munro, Ealasaid. n.d. “Feminism: A Fourth Wave?” Political Studies Association. https://www.psa.ac.uk/insight-plus/feminism-fourth-wave. Accessed 28 April 2017. 
Nussbaum, Martha. 1995. “Objectification.” Philosophy and Public Opinion 24.4: 249-

291.

O’Brien, Edna. 1964. Girls in Their Married Bliss. London: Cape.

Papadakis, Evangelina. 2015. "Feminist Perspectives on Objectification.” Stanford

Encyclopedia of Philosophy. http://plato.stanford.edu/entries/feminism-

objectification/. Accessed 28 April 2017.

Rich, Adrienne. 1976. Of Woman Born: Motherhood as Experience and as Institution.

New York: Norton.

Tolstoy, Leo. [1889] 1967. The Kreutzer Sonata. In Great Short Works of Leo Tolstoy.

Translated by L. and A. Maude. 359-449. New York: Perennial Library.

\footnotetext{
${ }^{1}$ This chapter is an abbreviated version of Kelso (2016). My thanks to The Bible and Critical Theory journal for allowing this reprint. Thanks also to the anonymous reviewers for their insightful comments and suggestions.

${ }^{2}$ See the White Ribbon website for details and access to the criminological research data behind these figures. Available online http://www.whiteribbon.org.au/white-ribbon-importance.

${ }^{3}$ On the question of whether a fourth wave is underway, see Munro (n.d.).

${ }^{4}$ A notable exception to this is Jenefsky with Russo (1998).

${ }^{5}$ Dworkin repeatedly uses this phrase "the God who does not exist" throughout Intercourse. She is gesturing at these points to Edna O’Brien who, in Girls in Their Married Bliss (1964) writes "Oh, God, who does not exist, you hate women, otherwise you'd have made them different."

${ }^{6}$ The most cited example of the sexism of the counter-cultural New Left is Stokely Carmichael's statement, in 1966, that "the only position for women in the SNCC [Student Non-violent Co-ordinating Committee] is prone." For a critical history of the problematic relationship between feminism and the New Left in the US, see Echols (2002), who, while obviously agreeing with the well-documented problems between feminists and the men of the New Left, nevertheless suggests that all was not as grim as feminists like Dworkin, Marge Piercy, and Robin Morgan would have it.

${ }^{7}$ Though see Brecher (2013). As part of its "Patriarchy 2013" series, The New Left Project included the topic "Why we should re-read Andrea Dworkin's 'Pornography: Men Possessing Women."' See also Lucas $(2011,74-81)$.

${ }^{8}$ In the Preface to the second edition of Intercourse (republished in the Twentieth Anniversary Edition), Dworkin explains: "In general women get to say yea or nay to intercourse, which is taken to be a synonym for sex, echt sex. In this reductive brave new world, women like sex or we do not. We are loyal to sex or we are not. The range of emotions and ideas expressed by Tolstoy et al. is literally forbidden to contemporary women. Remorse, sadness, despair, alienation, obsession, fear, greed, hateall of which men, especially male artists, express - are simple no votes for women. Compliance means yes; a simplistic rah-rah means yes; affirming the implicit right of men to get laid regardless of the consequences to women is a yes" (2006, xxxiii).

${ }^{9}$ Thanks to Erin Runions for reminding me of Bersani's essay.

${ }^{10}$ She is, in fact, responding to the depictions of intercourse given by the male authors she has analysed in the preceding six chapters, along with a passage from Edna O'Brien's Girls in Their Married Bliss, used as the epigraph to Chapter Seven "Occupation/Collaboration" (Dworkin 1987, 143).

${ }^{11}$ An alternative criticism comes from the stalwart liberal philosopher Martha Nussbaum, who insists on the potentially positive aspects of objectification during sex. See Nussbaum (1995), Papadaki (2015), and Lucas $(2011,74-81)$.

${ }^{12}$ See especially her interview with Michael Moorcock (Dworkin 1995).
} 
${ }^{13}$ The story is largely autobiographical (though Tolstoy never actually murdered his wife), as revealed by the diaries kept by the Countess, Sophie Tolstoy. See Dworkin (1987, 5-8).

${ }^{14}$ All biblical citations are taken from the JPSV.

${ }^{15}$ Genesis $4: 1 \mathrm{~b}$ is notoriously problematic because of the obvious suggestion that it is Yahweh, not Adam, who is the father of Cain.

${ }^{16}$ The idea of the impossibility of rape in marriage is usually traced to Matthew Hale, chief justice in seventeenth century England, who wrote: "But the husband cannot be guilty of a rape committed by himself upon his lawful wife, for by their mutual matrimonial consent and contract the wife hath given up herself in this kind unto the husband which she cannot retract" (Hale cited in Dworkin 1987, 194-5) ${ }^{17}$ See, for example McNally (2015), who reports on the growing ubiquity of online misogyny.

${ }^{18}$ For example, see Irigaray (2004). 